\title{
ANALISIS TINGKAT KEPUASAN WISATAWAN DOMESTIK TERHADAP PELAYANAN CUSTOMER SERVICE OFFICER DI BANDAR UDARA INTERNASIONAL I GUSTI NGURAH RAI BALI
}

\author{
Rahel Ambarita ${ }^{1}$, I Made Kusuma Negara ${ }^{2}$, I Ketut Suwena ${ }^{3}$ \\ Email : rahelambarita94@gmail.com ${ }^{1}$, kusuma.negara@unud.ac.id ${ }^{2}$, \\ suwena_ketut@yahoo.co.id ${ }^{3}$ \\ ${ }^{1,2,3}$ Program Studi Industri Perjalanan Wisata, Fakultas Pariwisata, Universitas Udayana
}

\begin{abstract}
The number of passenger complaints against facilities that have not been adequately then the CSO role is absolutely essential. This research aims to increase the tourist company shall use the services of our Customer Service Officer at Airport international lawyers I Gusti Ngurah Rai of Bali. The respondents in this research totalled 190 respondents, the selection of the sample using the method of purposive sampling, the data in this study were analyzed using the Importance Performance Analysis that help by statistikal program SPSS version 17.0 for windows. The results of this study are: 1) the level of satisfaction of tourists against the Customer Service Officer in general are at the level satisfied. 2) there are varying degrees of suitability that affect the satisfaction of tourists from each variable that is Tangible variables with percentage of $96.10 \%$, Reliability of $97.23 \%$, amounting to $95.90 \%$ Responsiveness, Assurance of $96.63 \%$ and Empathy of $95.93 \%$. 3) Indicator appearance and tidiness CSO is an indicator that needs to be maintained because of its implementation were in accordance with interest. 4) Indicator responsiveness of CSO in troubleshooting is an indicator of excessive in its execution.
\end{abstract}

Abstrak: Banyaknya keluhan penumpang terhadap fasilitas-fasilitas yang belum memadai maka peran CSO sangatlah penting. Penelitian ini bertujuan untuk perusahaan dalam meningkatkan wisatawan yang akan menggunakan jasa Customer Service Officerdi Bandar Udara Internasioanl I Gusti Ngurah Rai Bali. Responden dalam penelitian ini berjumlah 75 responden, pemilihan sampel menggunakan metode purposive sampling, data dalam penelitian dianalisis menggunakan Importance Performance Analysis yang di bantu oleh program statistikal SPSS version 17.0 for windows. Hasil penelitian ini adalah: 1) Tingkat kepuasan wisatawan terhadap pelayanan Customer Service Officersecara umum berada pada tingkat puas. 2) terdapatberbagai tingkatan kesesuian yang mempengaruhi kepuasan wisatawandari masing-masing variabel yaitu variabel Tangibledengan presentase sebesar 96.10\%, Reliabilitysebesar 97.23\%, Responsivenesssebesar 95.90\%, Assurance sebesar 96.63\% dan Empathy sebesar 95.93\%. 3) Indikator penampilan dan kerapian CSO merupakan indikator yang perlu dipertahankan karena pelaksanaannya telah sesuai dengan kepentingan. 4) Indikator Ketanggapan CSO dalam mengatasi masalah merupakan indikator yang berlebihan dalam pelaksanaannya.

Keywords: customer service officer, domestic tourist's satisfaction, international airport i gusti ngurah rai of bali.

\section{PENDAHULUAN}

Pariwisata merupakan suatu kegiatan yang dilakukan seseorang atau kelompok yang berpindah-pindah dari suatu tempat ke tempat lainnya dengan suatu perencanaan atau bukan maksud untuk mencari nafkah di tempat tujuannya berkunjung dalam kurun waktu sementara yang bertujuan hanya semata mata untuk mencari kesenangan dan hiburan serta beristirahat dari kegiatan sehari-hari yang membuat lelah dan penat. Pariwisata juga merupakan salah satu sektor yang sangat diandalkan dalam pembangunan nasional karena dapat meningkatkan pendapatan nasional dan pendapatan daerah serta devisa negara. Pariwisata juga berperan dalam menciptakan lapangan kerja serta mengurangi pengangguran sekaligus juga pariwisata dapat menciptakan kesejahteraan masyarakat.

Bali merupakan salah satu provinsi yang 
ada di Indonesia yang terkenal akan keindahan alam, aneka warisan sejarah budaya, serta terkenal dengan pulau Seribu Pura. Daya tarik wisata yang ada di Bali merupakan salah satu kekayaan alam yang patut untuk dibanggakan. Setiap daerah di Bali memiliki keunikan baik dari segi keindahannya maupun adat istiadat yang ada di daerah tersebut sehingga menarik minat wisatawan mancanegara maupun wisatawan nusantara untuk mengunjunginya. Jumlah kunjungan wisatawan macanegara dan domestik ke Bali setiap tahun mengalami peningkatan dan penurunan. Penurunan terjadi pada tahun 2014 tetapi tidak terlalu signifikan. Sedangkan pada tahun 2015 dan 2016 kunjungan wisatawan meningkat kembali. Diperkirakan peningkatan ini diakibatkan oleh munculnya peraturan Presiden Nomor 104 Tahun 2015 tentang peningkatan jumlah negara menjadi 90 negara yang mendapatkan fasilitas bebas visa dari kunjungan ke Indonesia (http://imigrasi.go.id). Ditahun 2016 juga muncul kembali peningkatan jumlah negara bebas visa kunjungan melalui peraturan Presiden No 21 Tahun 2016 mengenai penetapan 169 negara bebas visa kunjungan. Dengan adanya bebas visa kunjungan, wisatawan mancanegara dapat melakukan kunjungan Indonesia maksimal 30 hari. Oleh sebab itu, jumlah wisatawan yang berkunjung ke Bali sejak peraturan itu semakin meningkat. Dengan bertambahnya kunjungan wisatawan ke Bali, sarana dan prasarana pariwisata juga harus mampu bertahan dalam memberikan pelayanan yang baik bagi wisatawan. Salah satu kunci utama sebuah perjalanan wisata adalah alat transportasi yang akan digunakan wisatawan untuk berkunjung ke Bali. Karena alat Transportasi merupakan alat bantu untuk menghantarkan seseorang dari satu tempat ke tempat lain dengan waktu yang lebih singkat. Alat transportasi juga ada berbagai macam dan bentuk serta fungsinya. Terdapat tiga jenis transportasi yang digunakan di Indonesia, yaitu transportasi darat, laut, dan udara. Ketiga transportasi ini, transportasi tercepat ialah transportasi udara.Transportasi udara adalah transportasi yang lebih sering dan menjadi pilihan utama digunakan para wisatawan untuk berkunjung ke suatu tempat wisata. Transportasi udara beroperasi di Bandar udara. Provinsi Bali memiliki 1 bandara international yang di bawahi PT Angkasa Pura I (PERSERO), yaitu Bandar Udara Internasional I Gusti Ngurah
Rai Bali Berdiri sejak tahun 1930 di Jalan Raya Gusti Ngurah Rai, Tuban-Bali. Seluruh penerbangan baik keberangkatan dan kedatangan domestic maupun keberangkatan dan kedatangan internasional berpusat di bandara ini. Bandara I Gusti Ngurah Rai di pimpin oleh General Manager bernama Yunus Suprayogi dan Co. General Manager bernama I Gusti Ngurah Ardita SMS, QM, \& CS Department. Karena bandara I Gusti Ngurah Rai merupakan suatu pusat kegiatan penerbangan dari semua wisatawan yang akan datang ke Bali maupun wisatawan yang akan meninggalkan Bali setelah melakukan perjalanan baik itu berlibur, perjalanan bisnis, menuntut ilmu,kunjungan keluarga dan sebagainya sehingga pelayanan yang diberikan oleh bandara I Gusti Ngurah Rai harus memuaskan supaya dapat memberikan rasa puas dan menumbuhkan kepercayaan kepada para pengguna bandara sehingga para pengguna bandara merasa dirinya dipentingkan atau diperhatikan dengan baik dan benar. Pentingnya pelayanan yang memuaskan terhadap penumpang atau pengguna bandara juga merupakan strategi dalam menjaga nama baik perusahaan dan rasa puas pada penumpang dan para pengguna bandara . Akan tetapi, tidak cukup hanya memberikan rasa puas atau perhatian terhadap pengguna bandara, dalam hal ini adalah bagaimana cara merespon keinginan pengguna bandara ,sehingga dapat menimbulkan kesan positif dan juga harus ditunjang oleh kualitas sumber daya manusia yang handal juga.

Kualitas layanan yang diberikan oleh pihak bandara sangatlah penting bagi konsumen yang menggunakan jasa bandar udara. Konsumen harus merasa nyaman dengan layanan yang diberikan oleh pihak bandar udara, sehingga citra perusahaan akan baik dimata konsumennya. Disini fungsinya yang bukan hanya sebagai tempat menaikturunkan penumpang, barang atau cargo. Bandar udara yang memiliki berbagai macam fasilitas dan pelayanan yang baik telah mendapat respon dari SKYTRAX. SKYTRAX memberikan pengghargaan setiap tahunnya kepada bandar udara yang telah memiliki syarat sebagai bandar udara berkelas dunia (World Class Airport). Oliver (1980) mendefinisikan bahwa kepuasan adalah tingkat perasaan seseorang setelah membandingkan kinerja/hasil yang dirasakan 
dengan harapan. Akbar (2010) kepuasan konsumen merupakan tujuan dari berdirinya suatu usaha. Ini berarti kepuasan adalah tujuan utama suatu usaha karena apabila wisatawan puas maka usaha tersebut akan mendatangkan laba atau pendapatan bagi perusahaan. Menurut philip kotler (1994) untuk mengetahui kepuasan wisatawan dapat diketahui dari lima (5) aspek yaitu Bukti Fisik (tangibles), Keandalan (realiability), Daya Tanggap (responsiveness), Jaminan (assurance), dan Empati (empathy). Lima aspek tersebut sangat penting untuk ditingkatkan dan dikembangkan.

Penelitian berisi tentang analisis tingkat kepuasan wisatawan terhadap pelayanan customer service officer di bandara udara internasional I Gusti Ngurah Rai Bali penangananan keluhan oleh customer service di bandara internasional Ngurah Rai Bali,Yang menarik perhatian penulis dari kasus ini adalah banyaknya keluhan dari penumpang terhadap fasilitas-fasilitas yang belum memmadai baik di terminal keberangkatan dan kedatangan domestik maupun terminal keberangkatan dan kedatangan mancanegara. CSO harus bisa memberikan solusi pada penumpang tersebut sesuai dengan Standart Operating Procedure yang ada. Pelayanan yang sudah berjalan di bandara I Gusti Ngurah Rai sudah berjalan cukup baik namun ada beberapa hal yang sangat menyulitkan pengguna bandara dalam mendapatkan informasi dan juga menyulitkan customer service officer dalam memberikan informasi kepada pengguna bandara baik itu penumpang yang sudah tiba di bandara,calon penumpang yang akan melakukan penerbangan serta para pengguna bandara lainnya seperti pihak penjemputan dari hotel dan travel ini disebabkan karena keterbatasan dari sebagian fasilitas yang belum memadai di Bandara I Gusti Ngurah Rai. Namun ada juga beberapa prosedur pelayanan yang sudah berjalan dengan baik dan optimal seperti keberadaan toilet yang mencukupi sehingga dapat mengimbangi dari banyaknya kapasitas pengguna bandara, smoking room yang letaknya sudah strategis sehingga tidak menyulitkan bagi pengguna smoking room, Bantuan untuk penumpang penyandang disabilitas sangat dibutuhkan sehingga mereka dapat dengan mudah untuk mengakses bandara mulai dari penurunan penumpang sampai ke ruang tunggu dan sebaliknya.
Kebersihan yang selalu terjaga setiap hari karena banyaknya cleaning service yang selalu menjaga kebersihan dari bandara tersebut. Berdasarkan latar belakang di atas, maka penelitian ini mengangkat permasalahan tentang bagaimana analisis tingkat kepuasan wisatawan terhadap pelayanan customer service officer di Bandar udara internasional I Gusti Ngurah Rai Bali.

\section{METODE PENELITIAN}

Penelitian ini dilakukan di Bandar Udara Internasional I Gusti Ngurah Rai Bali, jalan Raya Gusti Ngurah Rai, Tuban-Bali. Penyebaran kuisioner dilakukan secara langsung ke lokasi penelitian kepada seluruh wisatawan yang menerima pelayanan dari customer service officer. Variabel pertama yang digunakan dalam penelitian ini serta untuk membatasi ruang lingkup permasalahan penelitian adalah kualitas pelayanan terhadap wisatawan (X), kualitas pelayanan yang dimaksud dalam penelitian ini adalah penilaian terhadap tingkat pelayanan yang diterima dengan tingkat pelayanan yang diharapkan. Kualitas pelayanan dapat diketahui dari persepsi para wisatawan atas pelayanan yang diterima dengan pelayanan yang diharapkan diukur melalui: Bukti nyata (tangible) adalah semua yang terlihat dan bisa diperhatikan langsung oleh wisatawan seperti: penampilan fisik, kebersihan dari petugas bandara atau customer service officer (1). Keandalan (reliability) adalah kemampuan customer service officer memberikan bantuan dengan baik, terpercaya, akurat dan konsisten (2). Daya tanggap (responsiveness) adalah kemauan dari customer service officer untuk membantu wisatawan dan memberikan jasa dengan cepat serta mendengar dan mengatsi keluhan wisatawan (3). Jaminan (assurance) adalah tingkat keyakinan yang mampu diwujudkan oleh customer service officer kepada wisatawan seperti penanganan terhadap keluhan yang diberikan kemampuan memberikan rasa aman. Aspek jaminan, meliputi: keramahan karyawan, keamanan, kepercayaan, dan keterampilan customer service officer untuk memberikan keyakinan kepada wisatawan (4). Dan Empati (empathy) adalah kesediaan customer service officer untuk lebih peduli memberikan perhatian secara pribadi kepada wisatawan dan pemahaman terhadap kebutuhan wisatawan (5). 
Variabel kedua yang digunakan dalam penelitian ini adalah tingkat kepuasan wisatawan terhadap kualitas pelayanan (Y). Tingkat kepuasan yang dimaksud dalam penelitian ini adalah pendapat dan tanggapan wisatawann setelah mendapatkan pelayanan sesuai harapan dan kepentingan wisatawan terhadap kinerja customer service officer, variabel kedua dibagi kedalam dua dimensi yaitu: (1) Kinerja (performance) merupakan pendapat wisatawan terhadap kenyataan kualitas pelayanan dari customer service officer di Bandar Udara I Gusti Ngurah Rai Bali. dan (2) Derajat kepentingan (Importance) adalah perasaan wisatawan terhadap derajat kepentingan setiap karakteristik kualitas pelayanan customer service officer Bandar Udara I Gusti Ngurah Rai Bali.

Teknik pengumpulan data dilakukan dengan observasi, dokumentasi, studi pustaka dan kuesioner. Teknik penentuan sampel dilakukan dengan purposive sampling, pengumpulan data dilakukan dengan penyebaran kuesioner terhadap 75 responden. Teknik Analisis data dilakukan dengan analisis deskriptif kuantitatif, tingkat kesesuaian, Importance Performance Analysis, tingkat kepuasan dan diagram kartesius.

Importance Performance Analysis atau analisis tingkat kepentingan dan kinerja yang diungkapkan oleh Martilla dan James dalam artikel yang dimuat di Journal of Marketing Januari 1997. Responden memberikan penilaian terhadap tingkat kepentingan dan kinerja terhadap setiap indikator yang disediakan. Pada tahap ini akan dicari skor penilaian terhadap faktor-faktor apa saja yang dapat mempengaruhi tingkat kepuasan wisatawan domestik terhadap pelayanan Customer Service Officer di Bandar Udara I Gusti Ngurah Rai Bali. Hasil yang diperoleh akan menunjukkan letak faktor-faktor yang mempengaruhi dalam diagram Kartesius. Dalam diagram Kartesius ini akan ada 18 titik sesuai dengan jumlah indikator yang ada dalam penelitian, di mana sumbu horizontal (X) akan diisi oleh skor tingkat kinerja. Sedangkan sumbu vertikal (Y) akan diisi oleh skor tingkat kepentingan.

\section{HASIL DAN PEMBAHASAN}

\section{Karakteristik Wisatawan}

Berdasarkan hasil penelitian kuisioner yang disebarkan secara menyuluruh maka diketahui karakteristik responden. Uraian mengenai karakteristik responden menyangkut tentang daerah asal, usia, jenis kelamin, status perkawinan, pekerjaan wisatawan domestic yang berkunjung ke Bali melalui Bandar Udara Internasional I Gusti Ngurah Rai Bali. Daerah asal wisatawan didominasi oleh asal Provinsi Sumatera Utara sebanyak $41.33 \%$. Wisatawan yang berasal dari Sumatera Utara lebih meminati untuk berkunjung ke Bali melalui Bandar Udara I Gusti Ngurah Rai karena wisatawan domestik asal Sumatera Utara perjalanan ke berbagai tempat ketimbang asal daerah lainnya di Indonesia. Usia wisatawan yang paling banyak berkunjung ke Bali melalui Bandar Udara I Gusti Ngurah Rai Bali adalah usia 19 - 25 tahun dengan presentase $74.67 \%$. Jenis kelamin wisatawan yang merasakan kepuasan pelayanan Customer Service Officer di Bandar Udara Internasional I Gusti Ngurah Rai Bali didominasi oleh perempuan sebesar $53.33 \%$. Status perkawinan wisatawan yang menggunakan pelayanan Customer Service Officer Bandar Udara I Gusti Ngurah Rai Bali didominasi oleh single sebesar $94.67 \%$. Pekerjaan wisatawan yang menggunakan pelayanan Customer Service Officer Bandar Udara I Gusti Ngurah Rai Bali didominasi oleh Pegawai Swasta sebesar $46.67 \%$ dan Pelajar/Mahasiswa sebesar 34.67\%.

\section{Analisis Tingkat Kepuasan}

Hasil penelitian tingkat kepuasan dan tingkat kinerja Customer Service Officer di Bandar Udara Internasional I Gusti Ngurah Rai Bali, maka dihasilkan suatu perhitungan mengenai tingkat kesesuaian antara kepentingan dan kinerja berikut.

\section{Indikator Bukti Nyata (Tangibility)}

1. Kenyamanan wisatawan saat bertanya kepada CSO.

Berdasarkan hasil dari penilaian 75 orang wisatawan terhadap pelayanan Customer Service Officer. Hasil tersebut mengindikasikan bahwa antara pelayanan dengan tingkat kepuasan wisatawan terhadap indikator kenyamanan wisatawan saat bertanya kepada CSO memiliki tingkat kesesuaian sebesar $93.93 \%$. Hal ini berarti wisatawan merasa sangat puas dengan kenyamanan saat bertanya kepada CSO. Rata-rata pelayanan yang diperoleh sebesar 3.92 yang berarti kinerja pelayanan CSO adalah baik. Berikutnya, skor rata-rata 
tingkat kepuasan wisatawan adalah sebesar 4.17. Hal ini berarti kepentingan wisatawan dengan kenyamanan saat bertanya kepada CSO adalah sangat penting.

2. Penampilan dan kerapian CSO

Berdasarkan hasil dari penilaian 75 orang wisatawan terhadap pelayanan Customer Service Officer. Hasil tersebut mengindikasikan bahwa antara pelayanan dengan tingkat kepuasan wisatawan terhadap indikator penampilan dan kerapian CSO memiliki tingkat kesesuaian sebesar $100.00 \%$. Hal ini berarti wisatawan merasa sangat puas dengan penampilan dan kerapian CSO. Rata-rata pelayanan yang diperoleh sebesar 4.21 yang berarti kinerja pelayanan CSO adalah sangat baik. Berikutnya, skor rata-rata tingkat kepuasan wisatawan adalah sebesar 4.21. Hal ini berarti kepentingan wisatawan dengan penampilan dan kerapian CSO adalah sangat penting.

3. Kelengkapan Counter CSO (telepon,speaker)

Berdasarkan hasil dari penilaian 75 orang wisatawan terhadap pelayanan Customer Service Officer. Hasil tersebut mengindikasikan bahwa antara pelayanan dengan tingkat kepuasan wisatawan terhadap indikator penampilan dan kerapian CSO memiliki tingkat kesesuaian sebesar $94.36 \%$. Hal ini berarti wisatawan merasa sangat puas dengan kelengkapan counter CSO. Rata-rata pelayanan yang diperoleh sebesar 4.01 yang berarti kinerja pelayanan CSO adalah baik. Berikutnya, skor rata-rata tingkat kepuasan wisatawan adalah sebesar 4.25. Hal ini berarti kepentingan wisatawan dengan kelengkapan counter CSO adalah sangat penting.

\section{Indikator Keandalan (Reliability)}

1. Penguasaan bahasa yang komunikatif dari CSO

Berdasarkan hasil dari penilaian 75 orang wisatawan terhadap pelayanan Customer Service Officer. Hasil tersebut mengindikasikan bahwa antara pelayanan dengan tingkat kepuasan wisatawan terhadap indikator penguasaan bahasa yang komunikatif dari CSO memiliki tingkat kesesuaian sebesar $98.41 \%$. Hal ini berarti wisatawan merasa sangat puas dengan penguasaan bahasa yang komunikatif dari CSO. Rata-rata pelayanan yang diperoleh sebesar 4.12 yang berarti kinerja pelayanan CSO adalah baik. Berikutnya, skor rata-rata tingkat kepuasan wisatawan adalah sebesar 4.19. Hal ini berarti kepentingan wisatawan dengan penguasaan bahasa yang komunikatif dari CSO adalah penting.

2. CSO sudah terlatih melayani wisatawan Berdasarkan hasil dari penilaian 75 orang wisatawan terhadap pelayanan Customer Service Officer. Hasil tersebut mengindikasikan bahwa antara pelayanan dengan tingkat kepuasan wisatawan terhadap indikator CSO sudah terlatih melayani wisatawan memiliki tingkat kesesuaian sebesar $94.59 \%$. Hal ini berarti wisatawan merasa sangat puas dengan CSO sudah terlatih melayani wisatawan. Rata- rata pelayanan yang diperoleh sebesar 3.96 yang berarti kinerja pelayanan CSO adalah baik. Berikutnya, skor ratarata tingkat kepuasan wisatawan adalah sebesar 4.19. Hal ini berarti kepentingan wisatawan dengan CSO sudah terlatih melayani wisatawan adalah penting.

3. CSO mengarahkan dengan jelas tempat/lokasi yang ditanyakan wisatawan (toilet,check in / check out counter dll)

Berdasarkan hasil dari penilaian 75 orang wisatawan terhadap pelayanan Customer Service Officer. Hasil tersebut mengindikasikan bahwa antara pelayanan dengan tingkat kepuasan wisatawan terhadap indikator CSO mengarahkan dengan jelas tempat/lokasi yang ditanyakan wisatawan memiliki tingkat kesesuaian sebesar $98.71 \%$. Hal ini berarti wisatawan merasa sangat puas dengan CSO mengarahkan dengan jelas tempat/lokasi yang ditanyakan wisatawan. Rata-rata pelayanan yang diperoleh sebesar 4.07 yang berarti kinerja pelayanan CSO adalah baik. Berikutnya, skor rata-rata tingkat kepuasan wisatawan adalah sebesar 4.12. Hal ini berarti kepentingan wisatawan dengan CSO mengarahkan dengan jelas tempat/lokasi yang ditanyakan wisatawan adalah penting.

\section{Indikator Daya Tanggap (Responsiveness)}

1. Sikap menghargai wisatawan dalam memberi pelayanan.

Berdasarkan hasil dari penilaian 75 orang wisatawan terhadap pelayanan Customer 
Service Officer. Hasil tersebut mengindikasikan bahwa antara pelayanan dengan tingkat kepuasan wisatawan terhadap indikator sikap menghargai wisatawan dalam memberi pelayanan memiliki tingkat kesesuaian sebesar 97.13\%. Hal ini berarti wisatawan merasa sangat puas dengan sikap menghargai wisatawan dalam memberi pelayanan. Rata-rata pelayanan yang diperoleh sebesar 4.07 yang berarti kinerja pelayanan CSO adalah baik. Berikutnya, skor rata-rata tingkat kepuasan wisatawan adalah sebesar 4.19. Hal ini berarti kepentingan wisatawan dengan sikap menghargai wisatawan dalam memberi pelayanan adalah penting.

2. Pelayanan yang tepat dan efisien

Berdasarkan hasil dari penilaian 75 orang wisatawan terhadap pelayanan Customer Service Officer. Hasil tersebut mengindikasikan bahwa antara pelayanan dengan tingkat kepuasan wisatawan terhadap indikator pelayanan yang tepat dan efisien memiliki tingkat kesesuaian sebesar $96.43 \%$. Hal ini berarti wisatawan merasa sangat puas dengan pelayanan yang tepat dan efisien. Rata-rata pelayanan yang diperoleh sebesar 3.96 yang berarti kinerja pelayanan CSO adalah baik. Berikutnya, skor rata-rata tingkat kepuasan wisatawan adalah sebesar 4.11. Hal ini berarti kepentingan wisatawan dengan pelayanan yang tepat dan efisien adalah penting.

3. Ketanggapan CSO dalam mengatasi masalah.

Berdasarkan hasil dari penilaian 75 orang wisatawan terhadap pelayanan Customer Service Officer. Hasil tersebut mengindikasikan bahwa antara pelayanan dengan tingkat kepuasan wisatawan terhadap indikator ketanggapan CSO dalam mengatasi masalah memiliki tingkat kesesuaian sebesar $92.90 \%$. Hal ini berarti wisatawan merasa sangat puas dengan ketanggapan CSO dalam mengatasi masalah. Rata-rata pelayanan yang diperoleh sebesar 3.84 yang berarti kinerja pelayanan CSO adalah baik. Berikutnya, skor rata-rata tingkat kepuasan wisatawan adalah sebesar 4.13. Hal ini berarti kepentingan wisatawan dengan ketanggapan CSO dalam mengatasi masalah adalah penting.

4. Inisiatif CSO dalam membantu wisatawan
Berdasarkan hasil dari penilaian 75 orang wisatawan terhadap pelayanan Customer Service Officer. Hasil tersebut mengindikasikan bahwa antara pelayanan dengan tingkat kepuasan wisatawan terhadap indikator inisiatif CSO dalam membantu wisatawan memiliki tingkat kesesuaian sebesar $98.36 \%$. Hal ini berarti wisatawan merasa sangat puas dengan inisiatif CSO dalam membantu wisatawan. Rata- rata pelayanan yang diperoleh sebesar 4.00 yang berarti kinerja pelayanan CSO adalah baik. Berikutnya, skor rata-rata tingkat kepuasan wisatawan adalah sebesar 4.07. Hal ini berarti kepentingan wisatawan dengan inisiatif CSO dalam membantu wisatawan adalah penting.

\section{Indikator Jaminan (Assurance)}

1. CSO bersikap sopan dan ramah saat melayani wisatawan

Berdasarkan hasil dari penilaian 75 orang wisatawan terhadap pelayanan Customer Service Officer. Hasil tersebut mengindikasikan bahwa antara pelayanan dengan tingkat kepuasan wisatawan terhadap indikator CSO bersikap sopan dan ramah saat melayani wisatawan memiliki tingkat kesesuaian sebesar $96.81 \%$. Hal ini berarti wisatawan merasa sangat puas dengan CSO bersikap sopan dan ramah saat melayani wisatawan. Rata-rata pelayanan yang diperoleh sebesar 4.04 yang berarti kinerja pelayanan CSO adalah baik. Berikutnya, skor rata-rata tingkat kepuasan wisatawan adalah sebesar 4.17. Hal ini berarti kepentingan wisatawan dengan CSO bersikap sopan dan ramah saat melayani wisatawan adalah penting.

2. Bertanggung jawab atas jawaban yang diberikan kepada wisatawan

Berdasarkan hasil dari penilaian 75 orang wisatawan terhadap pelayanan Customer Service Officer. Hasil tersebut mengindikasikan bahwa antara pelayanan dengan tingkat kepuasan wisatawan terhadap indikator bertanggung jawab atas jawaban yang diberikan kepada wisatawan memiliki tingkat kesesuaian sebesar $96.46 \%$. Hal ini berarti wisatawan merasa sangat puas dengan tanggung jawab atas jawaban yang diberikan kepada wisatawan. Rata-rata pelayanan yang diperoleh sebesar 4.00 yang berarti kinerja pelayanan CSO adalah baik. Berikutnya, skor rata-rata 
tingkat kepuasan wisatawan adalah sebesar 4.15. Hal ini berarti kepentingan wisatawan dengan tanggung jawab atas jawaban yang diberikan kepada wisatawan adalah penting.

\section{Indikator Empati (Empathy)}

1. Perhatian CSO terhadap pertanyaan wisatawan

Berdasarkan hasil dari penilaian 75 orang wisatawan terhadap pelayanan Customer Service Officer. Hasil tersebut mengindikasikan bahwa antara pelayanan dengan tingkat kepuasan wisatawan terhadap indikator perhatian CSO terhadap pertanyaan wisatawan memiliki tingkat kesesuaian sebesar $95.82 \%$. Hal ini berarti wisatawan merasa sangat puas dengan perhatian CSO terhadap pertanyaan wisatawan. Rata-rata pelayanan yang diperoleh sebesar 3.97 yang berarti kinerja pelayanan CSO adalah baik. Berikutnya, skor rata-rata tingkat kepuasan wisatawan adalah sebesar 4.15. Hal ini berarti kepentingan wisatawan dengan perhatian CSO terhadap pertanyaan wisatawan adalah penting.

2. Perhatian CSO terhadap keinginan dan kebutuhan wisatawan

Berdasarkan hasil dari penilaian 75 orang wisatawan terhadap pelayanan Customer Service Officer. Hasil tersebut mengindikasikan bahwa antara pelayanan dengan tingkat kepuasan wisatawan terhadap indikator perhatian CSO terhadap keinginan dan kebutuhan wisatawan memiliki tingkat kesesuaian sebesar $96.43 \%$. Hal ini berarti wisatawan merasa sangat puas dengan perhatian CSO terhadap keinginan dan kebutuhan wisatawan. Rata-rata pelayanan yang diperoleh sebesar 3.96 yang berarti kinerja pelayanan CSO adalah baik. Berikutnya, skor rata-rata tingkat kepuasan wisatawan adalah sebesar 4.11. Hal ini berarti kepentingan wisatawan dengan perhatian CSO terhadap keinginan dan kebutuhan wisatawan adalah penting.

3. Perhatian CSO terhadap keluhan wisatawan

Berdasarkan hasil dari penilaian 75 orang wisatawan terhadap pelayanan Customer Service Officer. Hasil tersebut mengindikasikan bahwa antara pelayanan dengan tingkat kepuasan wisatawan terhadap indikator perhatian CSO terhadap keluhan wisatawan memiliki tingkat kesesuaian sebesar $95.53 \%$. Hal ini berarti wisatawan merasa sangat puas dengan perhatian CSO terhadap keluhan wisatawan. Rata-rata pelayanan yang diperoleh sebesar 3.99 yang berarti kinerja pelayanan CSO adalah baik. Berikutnya, skor rata-rata tingkat kepuasan wisatawan adalah sebesar 4.17. Hal ini berarti kepentingan wisatawan dengan perhatian CSO terhadap keluhan wisatawan adalah penting. Berdasarkan Tabel 2 diatas, ratarata skor $\mathrm{X}$ dan $\mathrm{Y}$ untuk indikator bukti nyata (Tangible) adalah sebesar 4.05 dan 4.21 dengan tingkat kesesuaian sebesar $96.10 \%$ dengan kriteria sangat puas. Rata rata skor $\mathrm{X}$ dan $\mathrm{Y}$ untuk indikator keandalan (Reliability) yaitu sebesar 4.05 dan 4.16 dengan tingkat kesesuaian sebesar 97.23\% yaitu dengan kriteria sangat puas. Selanjutnya untuk indikator daya tanggap (Responsiveness) rata - rata skor X dan $\mathrm{Y}$ yaitu sebesar 3.93 dan 4.10 dengan tingkat kesesuaian sebesar $95.90 \%$ dengan kriteria sangat puas. Pada indikator jaminan (Assurance) rata - rata skor X dan Y yaitu sebesar 4.02 dan 4.16 dengan tingkat kesesuaian sebesar $96.63 \%$ dengan kriteria sangat puas. Sedangkan untuk indikator empati (Empathy) rata - rata skor X dan Y yaitu sebesar 3.97 dan 4.14 dengan tingkat kesesuaian sebesar $95.93 \%$ dengan kriteria sangat puas. Dengan demikian, dapat dikatakan wisatawan merasa puas dengan pelayanan Customer Service Officer di Bandar Udara Internasional I Gusti Ngurah Rai Bali. Maka dari itu, pihak bandara lebih baik meningkatkan kualitas pelayanan agar menjadi lebih baik lagi daripada saat ini.

\section{Importance Performance Analysis}

Importance Performance Analysis (analsis derajat kepentingan-kinerja) digunakan untuk mengetahui faktor/indikator dari tingkat kepuasan dan kualitas pelayanan Customer Service Officer. Untuk dapat mengetahui faktor/indikator tersebut dalam diagram Kartesius maka ditentukan terlebih dahulu dua buah titik X dan Y yang akan membentuk dua buah garis berpotong membatasi empat bagian dalam diagram Kartesius. Perhitungan $\mathrm{X}$ merupakan rata-rata dari rata-rata skor tingkat kinerja seluruh indikator, ditentukan dengan 
rumus sebagai berikut:

Gambar 1 Diagram Kartesius

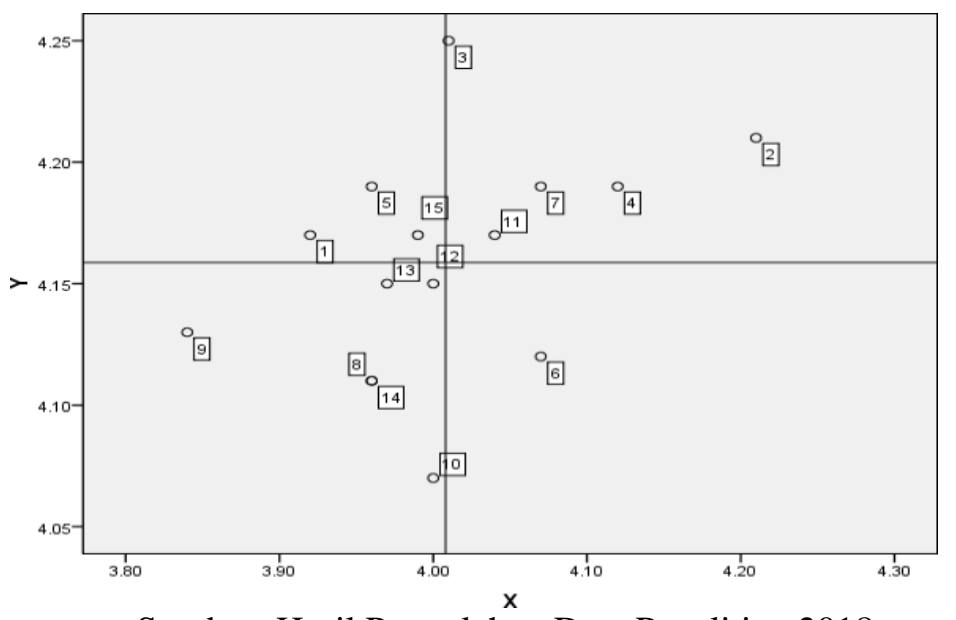

Sumber; Hasil Pengolahan Data Penelitian 2018.

Berdasarkan Gambar 1 dapat dilihat bahwa letak indikator pelayanan Customer Service Officer yang mempengaruhi tingkat kepuasan wisatawan terbagi ke dalam empat bagian pada diagram kartesius seperti berikut:

\section{Kuadran A (Prioritas utama)}

Kuadran A menunjukan faktor/indikator yang mempengaruhi kepuasan wisatawan. Faktor/indikator yang berada dalam kuadran ini perlu diprioritaskan oleh perusahaan karena indikator tersebut dianggap sangat penting oleh wisatawan. Sedangkan tingkat kinerja/pelaksanaannya masih belum memuaskan. Adapun faktor/indikator yang termasuk dalam kuadran ini adalah:

1. Kenyamanan wisatawan saat bertanya kepada CSO (1)

2. CSO sudah terlatih melayani wisatawan (5)

3. Perhatian CSO terhadap keluhan wisatawan (15)

\section{Kuadran B (Pertahankan prestasi)}

Kuadran B menunjukan faktor/indikator yang mempengaruhi kepuasan wisatawan. Faktor/indikator yang berada dalam kuadran ini dinilai perlu dipertahankan karena dianggap telah baik dilaksanakan oleh Customer Service Officer serta tingkat kinerja/pelaksanaannya sesuai dengan tingkat pelayanan dan kepuasan wisatawan. Adapun faktor/indikator yang termasuk dalam kuadran ini adalah:

1. Penampilan dan kerapian CSO (2)

2. Kelengkapan Counter CSO (3)

3. Penguasaan bahasa yang komunikatif dari

\section{CSO (4)}

4. Sikap menghargai wisatawan dalam memberi pelayanan (7)

5. CSO bersikap sopan dan ramah saat melayani wisatawan (11)

\section{Kuadran C (Prioritas rendah)}

Kuadran $\mathrm{C}$ menunjukan faktor/indikator yang mempengaruhi kepuasan wisatawan. Faktor/indikator yang berada dalam kuadran ini dinilai kurang penting oleh wisatawan, sedangkan kinerja/pelaksanannya dinilai telah baik. Adapun faktor/indikator yang termasuk dalam kuadran ini adalah:

1. Pelayanan yang tepat dan efisien (8)

2. Ketanggapan CSO dalam mengatasi masalah (9)

3. Inisiatif CSO dalam membantu wisatawan (10)

4. Bertanggung jawab atas jawaban yang diberikan kepada wisatawan (12)

5. Perhatian CSO terhadappertanyaan wisatawan (13)

6. Perhatian CSO terhadap keinginan dan kebutuhan wisatawan (14)

\section{Kuadran D (Berlebihan)}

Kuadran D menunjukan faktor/indikator yang mempengaruhi kepuasan wisatawan. Faktor/indikator yang berada dalam kuadran ini dinilai pelaksanaannya berlebihan. Hal ini dikarenakan wisatawan menganggap kurang penting atau tidak penting, namun dilaksanakan dengan baik atau sangat baik oleh Customer Service Officer. Adapun 
faktor/indikator yang termasuk dalam kuadran ini adalah CSO mengarahkan dengan jelas tempat/lokasi yang ditanyakan wisatawan (toilet,check in/check out counter dll) (6).

Analisis tingkat kepuasan wisatawan terhadap pelayanan customer service officer di Bandar udara internasional I Gusti Ngurah Rai Bali, menunjukan bahwa kepuasan wisatawan berada pada kategori sangat puas dengan persentase tingkat kesesuaian variabel antara 95.90\% dalam variabel responsiveness sampai $97.23 \%$ dalam variabel reliability. Oleh karena itu variabel reliability merupakan salah satu faktor yang dapat mempengaruhi kepuasan wisatawan terhadap pelayanan customer service officer di Bandar udara internasional I Gusti Ngurah Rai Bali.

Penelitian ini sesuai dengan penelitian yang dilakukan oleh Sanyoto (2011) yang menyatakan bahawa variabel responsiveness merupakan salah satu variabel terendah yang mempengaruhi kepuasan konsumen terhadap pelayanan Centro futsal Yogyakarta. Kemudian penelitian yang dilakukan oleh Ramadhani et.al (2014) yang menyatakan bahawa variabel reliability merupakan salah satu varibel tertinggi yang mempengaruhi kepuasan konsumen terhadap kinerja pelayanan pemasok bunga potong krisan Malang. Sedangkan penelitian yang dilakukan oleh Irawati et.al (2010) yang menyatakan bahwa variabel responsiveness merupakan salah satu variabel tertinggi dari kepuasan pelanggan Bandar Udara Hang Nadim Batam, hasil dari penelitian ini berlawanan dengan penelitian yang dilakukan oleh peneliti. Selanjutnya penelitian yang dilakukan oleh Hermanto (2008) yang menyatakan bahwa variabel reliability merupakan salah satu variabel terendah kedua setelah variabel responsiveness dari kepuasan konsumen terhadap pelayanan terminal peti kemas Semarang, hasil dari penelitian ini juga bertolak belakang dengan penelitian yang dilakukan oleh peneliti.

Berdasarkan hasil observasi peran dari CSO itu sendiri tidak terlalu baik dalam menangani permasalaha karena terdapat atasan yang akan menangani permasalahan mereka ketika adanya masalah yang terjadi antara CSO dengan pihak lainnya. Sedangkan penampilan dan kerapian CSO sangat baik karena CSO bekerja di Bandara yang memiliki standar internasional dan destinasi terbaik di Indonesia. Jadi penampilan dan kerapian CSO ketika bekerja lebih rapi dibandingkan dengan peran lainnya yang ada dalam Bandara I Gusti Ngurah Rai.

\section{SIMPULAN DAN SARAN Simpulan}

Berdasarkan hasil pembahasan dapat disimpulkan tingkat kepuasan wisatawan domestik terhadap pelayanan Customer Service Officer di Bandar Udara Internasional I Gusti Ngurah Rai Bali dapat dikatakan puas dengan pelayanan yang diberikan oleh Customer Service Officer dengan tingkat kesesuaian sebesar $96.10 \%$ dengan kriteria sangat puas untuk variabel bukti nyata (Tangible), tingkat kesesuaian sebesar $97.23 \%$ dengan kriteria sangat puas untuk variabel keandalan (Reliability), tingkat kesesuaian sebesar 95.90\% dengan kriteria sangat puas untuk variabel daya tanggap (Responsiveness), tingkat kesesuaian sebesar $96.63 \%$ dengan kriteria sangat puas untuk variabel jaminan (Assurance), tingkat kesesuaian sebesar 95.93\% dengan kriteria sangat puas untuk variabel empati (Empathy)

\section{Saran}

1. Perhatian Customer Service Officer CSO Bandar Udara I Gusti Ngurah Rai harus menunjukan wajah yang ramah dalam keadaan apapun.

2. Perlu lebih dapat peduli terhadap keluhan wisatawan. Hal yang disebutkan dalam saran penelitian ini bertujuan untuk tingkat kepuasan lebih tinggi oleh wisatawan terhadap pelayanan Customer Service Officer di Bandar Udara I Gusti Ngurah Rai, Bali.

3. CSO harus menjaga nama daerah tujuan wisata terbaik didunia menurut Internasional Traveler Choice Award, 2017. 


\section{Kepustakaan}

Anonim, 2009. Undang-Undang Republik Indonesia No. 10 Tahun 2009 Tentang Kepariwisataan.

, 1990. Undang-Undang Republik Indonesia Nomor 9 tahun 1990 tentang Kepariwisataan.

Arikuntoro, 2002. Prosedur Penelitian. Jakarta: Renika Cipta

Kotler, P. 2000. Marketing Management.Millenium Edition. NJ: Pearson.

Kusmayadi, I.R. \& Sugiarto, 2000, Metodologi Penelitian dalam Bidang Kepariwisataan. Jakarta: PT. Gramedia Pustaka Utama.

Liu, Xiaoming, Li, Jun (Justin), Kim, Woo Gon, 2015."The role of travel experience in the structural relationships among tourists' perceived image, satisfaction, and behavioral intentions". Journal Tourism and Hospitality Reasearch.

Margono. 2003. Metode Penelitian Pendidikan. Jakarta: PT Asdi Mahasatya.

Miro, F. 2005. Perencanaan Transportasi untuk Mahasiswa, Perencana, dan Praktisi. Erlangga. Jakarta.

Moh. Nazir .2005. Metode Penelitian. Jakarta: Ghalia Indonesia.

Parasuraman, A., Valarie A. Zeithaml, and Leonard L. Berry. 1985." A Conseptual Model of Service Quality and Its Implication for Future Research". Journal of Marketing, Vol. 49 (fall).

Pendit. Nyoman S. 2002. Ilmu Pariwisata Sebuah Pengantar Perdana. Jakarta: PT. Pradnya Paramita.

Pitana, Gede. 2005. Sosiologi Pariwisata.Jakarta: Pradnya Paramita

Pitana, I Gde. dan Surya Diarta, I Ketut. 2009. Pengantar Ilmu Pariwisata. Yogyakarta: Penerbit Andi.
Purwoko. B. A. 2000. Kepuasan danLoyalitas: Perspektif Kualitas Layanan. Jakarta: Komunika JayaPratama.

Rambat Lupiyoadi. (2001). Manajemen Pemasaran Jasa (Teori dan Praktek). Edisi Pertama. Penerbit Salemba Empat, Depok.

Siboro, Surya, Millanyani, Heppy. "Customer Satisfaction Analysis Using Importance Performance Analysis (Case Study on Dealer Service Centers Anugrah Motor workshop in Bandung Soang Bojong Canal)". Jurnal Manajemen Bisnis Telekomunikasi dan Informatika.

Soebiyantoro, Ugy "Pengaruh Ketersediaan Sarana Prasarana, Sarana Transportasi Terhadap Kepuasan Wisatawan". Jurnal Manajemen Pemasaran, Vol. 4, No. 1, April 2009: 16-22.

Soekadijo. 2000. Anatomi Pariwista. Jakarta: Gramedia.

Suardana, I Wayan , Suwena, I Ketut, Leli Kusuma Dewi, Luh Gede "Tingkat Kepuasan Wisatawan Terhadap Kualitas Pelayanan Shuttle Bus Komotra Bali Di Central Park Kuta", Jurnal IPTA Vol.1 NO.1, 2013.

Sugiyono. 2007. Metode Penelitian Kuantitatif Kualitatif dan R\&D. Bandung: Alfabeta.

___ , 2009, Metode Penelitian Kuantitatif, Kualitatif, dan R\&D. Bandung: Alfabeta.

Sunarto. 2003. Perilaku Konsumen. Yogyakarta: AMUS Yogyakarta dan CV. Ngeksigondo Utama.

Supranto, J.2006.Pengukuran Tingkat Kepuasan Pelanggan.Jakarta: PT.Rineka

___ 2011. Pengukuran Tingkat Kepuasan Pelanggan. Jakarta: PT Rineka Cipta.

Suwardi, Utomo, Joko. Analisis Manajemen Vol. 5, no. 1, 2011:81.

Tjiptono, Fandy. 2004. Manajemen Jasa, Edisi 
Kedua. Penerbit ANDI. Yogyakarta.

2012. Service Management: Mewujudkan Layanan Prima. Yogyakarta: Penerbit Andi.

Tse dan Wilton (1988). Kepuasan Pelanggan, jilid 2. Edisi ketiga. Klaten: PT. Indeks Kelompok Gramedia.

Wirajaya, Yessy "Analisis Kepuasan Wisatawan Mancanegara Terhadap Kualitas Pelayanan Pariwisata". Jurnal Manajemen dan Akuntansi Volume 2, Nomor 3, Desember 2013.

Yoeti, Oka. A Edisi Revisi 1996, Pengantar Ilmu Pariwisata, Penerbit Angkasa, Bandung. 